HNF-29267-FP

Revision 0

The Challenges of

Preserving Historic

Resources During the

Deactivation and

Decommissioning of

Highly Contaminated

Historically Significant

Plutonium Process

Facilities.

Prepared for the U.S. Department of Energy

Assistant Secretary for Environmental Management

Project Hanford Management Contractor for the

U.S. Department of Energy under Contract DE-AC06-96RL13200

FLUOR.

P.O. Box 1000

Richland, Washington

Approved for Public Release;

Further Dissemination Unlimited 
HNF-29267-FP

Revision 0

\section{The Challenges of Preserving Historic Resources During the Deactivation and Decommissioning of Highly Contaminated Historically Significant Plutonium Process Facilities}

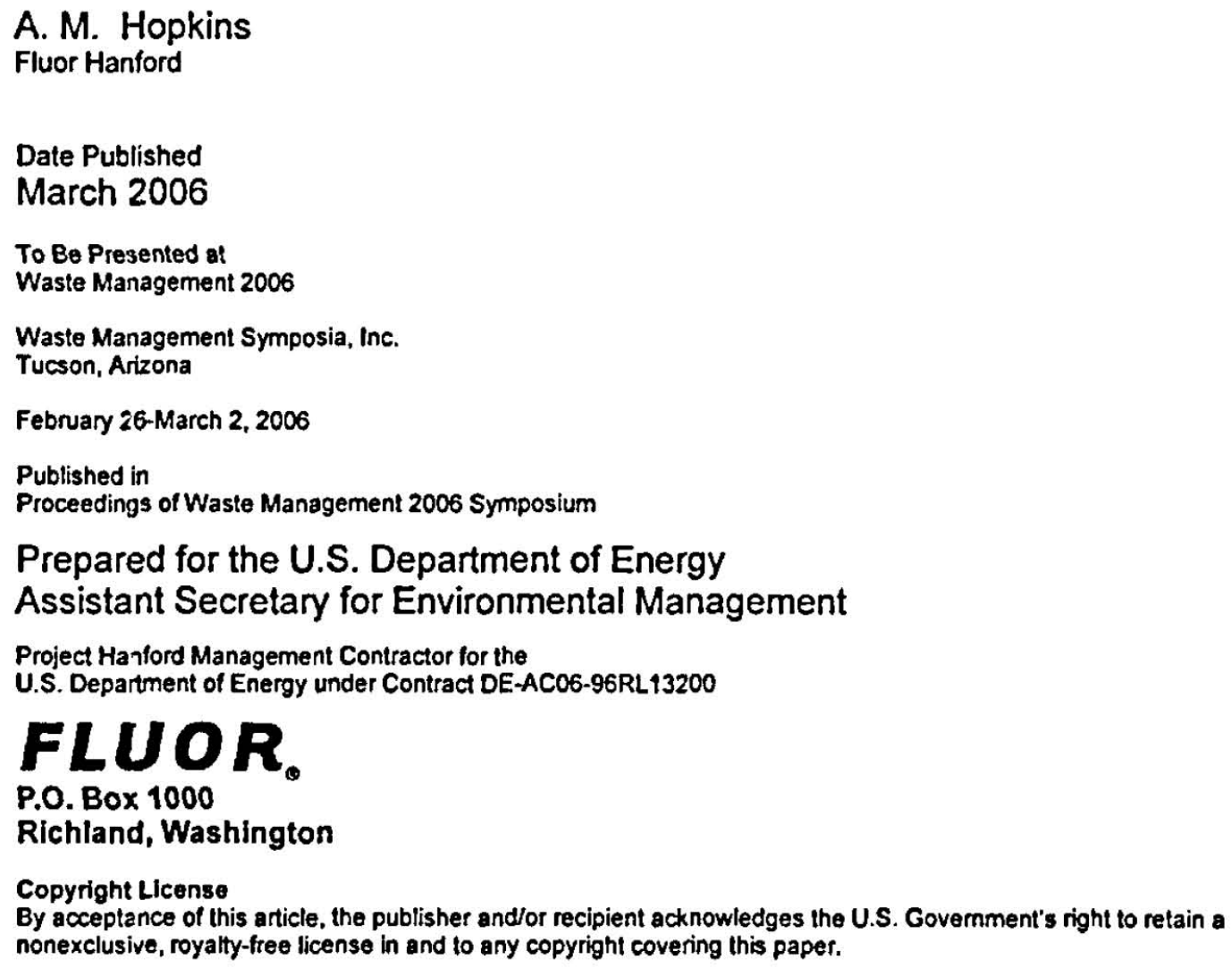

Approved for Public Release; Further Dissemination Unlimited 
HNF-29267-FP

Revision 0

LEGAL DISCLAIMER

This report was prepared as an account of work sponsored by an agency of the United States Govemment. Neither the United States Government nor any agency thereof, nor any of their employees, nor any of their contractors, subcontractors or their employees, makes any warranty, express or implied, or assumes any legal liability or responsibility for the accuracy. completeness, or any third party's use or the results of such use of any information, apparatus, product, or process disclosed, or represents that its use would not infringe privately owned rights. Reference herein to any specific commercial product, process, or service by trade name, trademark, manufacturer, or otherwise, does not necessarily constitute or imply its endorsement, recommendation, or favoring by the United States Government or any agency thereof or its contractors or subcontractors. The views and opinions of authors expressed herein do not necessarily state or reflect those of the United States Government or any agency thereof.

This report has been reproduced from the best available copy. Available in paper copy. 
WM'06 Conference, February 26 - March 2, 2006, Tucson, AZ

\title{
THE CHALLENGES OF PRESERVING HISTORIC RESOURCES DURING THE DEACTIVATION AND DECOMMISSIONING OF HIGHLY CONTAMINATED HISTORICALLY SIGNIFICANT PLUTONIUM PROCESS FACILITIES
}

\author{
A. Hopkins, M. Minette, D. Sorenson, R. Heineman, M. Gerber \\ Fluor Hanford, Inc. PO Box 1000 Richland WA 99352 \\ S. Charboncau \\ US Department of Energy, PO Box 550, Richland WA 99352 \\ F. Bond \\ Washington State Department of Ecology, WDOE, 3100 Port of Benton Blvd., \\ Richland WA, 99354
}

\begin{abstract}
The Manhattan Project was initiated to develop nuclear weapons for use in World War II. The Hanford Engineer Works (HEW) was established in eastern Washington State as a production complex for the Manhattan Project. A major product of the HEW was plutonium. The buildings and process equipment used in the early phases of nuclear weapons development are historically significant because of the new and unique work that was performed. When environmental cleanup became Hanford's central mission in 1991, the Department of Energy (DOE) prepared for the deactivation and decommissioning of many of the old process facilities. In many cases, the process facilities were so contaminated, they faced demolition. The National Historic Preservation Act (NHPA) requires federal agencies to evaluate the historic significance of properties under their jurisdiction for eligibility for inclusion in the National Register of Historic Places before altering or demolishing them so that mitigation through documentation of the properties can occur. Specifically, federal agencies are required to evaluate their proposed actions against the effect the actions may have on districts, sites, buildings or structures that are included or eligible for inclusion in the National Register.
\end{abstract}

In an agreement between the DOE's Richland Operations Office (RL), the Washington State Historic Preservation Office (SHPO) and the Advisory Council on Historic Preservation (ACHP), the agencies concurred that the Hanford Site Historic District is eligible for listing on the National Register of Historic Places and that a Sitewide Treatment Plan would streamline compliance with the NHPA while allowing RL to manage the cleanup of the Hanford Site. Currently, many of the old processing buildings at the Plutonium Finishing Plant (PFP) are undergoing deactivation and decommissioning. RL and Fluor Hanford project managers at the PFP are committed to preserving historical artifacts of the plutonium production process. They must also ensure the safety of workers and the full decontamination of buildings or artifacts if they are to be preserved. This paper discusses the real time challenges of working safely, decontaminating process equipment, preserving historical structures and artifacts and documenting their history at PFP.

\section{INTRODUCTION}

In 1942 the U.S. Army Corps of Engineers (USACE) formed a new district devoted entirely to the mission of atomic weapons development called the Manhattan Engineer District. The effort to develop an atomic weapon became known as the "Manhattan Project". The purpose of the 
Hanford Site in the Manhattan Project was chemical separations and industrial scale plutonium production. The Manhattan Project included buildings ranging from reactors, chemical separation plants, laboratories, warehouses, electrical facilities and craft shops. These facilities continued to operate after World War II as the nuclear arms race extended into the Cold War.

When the U.S. Department of Energy Richland Operations Office (DOE-RL) began environmental cleanup activities on the Hanford Site, the deactivation and demolition (D\&D) of many of its process facilities was determined to be necessary. As a federal agency, RL has the responsibility for the preservation of all historic buildings and structures under its management. RL determined that the D\&D activities could have an adverse effect on historic buildings at Hanford. Consequently, RL, the Washington State Historic Preservation Officer (SHPO) and the Advisory Council on Historic Preservation (ACHP) concurred in a Programmatic Agreement (DOE/RL-96-77) [1] that the Hanford Site Historic District is eligible for listing on the Register and that a plan would be developed to streamline compliance with the NHIPA primarily through identification of historical properties and planned mitigation efforts.

Plutonium production was the major mission of the Hanford Site. PFP conducted the final step in plutonium metal production beginning in 1949 and throughout the Cold War. Following the Site Treatment Plan, an historical and cultural working group evaluated the built environment at PFP. As a result of this evaluation, 10 buildings at PFP were designated as having historic significance. These buildings are: $234-5 Z / 234-5 Z A, 236-Z, 242-Z, 2701-Z A, 2704-Z, 2736-Z$, 2736-ZA, 2736-ZB, 291-Z and 232-Z. The PFP or $234 / 5-Z$ is the major facility in the PFP complex of buildings. Unfortunately, these buildings are so contaminated they cannot be decontaminated but must be demolished. As a result, mitigation through documentation is required.

The NHPA requires the following for documentation:

Documentation is a detailed record, in the form of a report of other written document, of the historic context(s) and significance of a property. Historical research to create documentation uses archival materials, oral history techniques, ethno histories, prior research contained in secondary sources and other sources to make a detailed record of previously identified values or to investigate particular questions about the established significance of a property or properties... Documentation generally results in both greater factual knowledge about the specific property and its values, and in better understanding of the property in its historical context.... 48 FR 44716.

The DOE and its contractors are committed to preserving the history of the Manhattan Project Cold War Era Historic District to the extent practicable as required by the NHPA. They face the challenge of preserving historically significant buildings and artifacts while accomplishing the D\&D work. While project managers at the PFP work ton preserve historical artifacts of the plutonium production process they must at the same time ensure the safety of workers and the full decontamination of the artifacts. This effort sometimes requires changes in schedule or work evolutions to ensure artifacts are preserved or fully documented. 
WM'06 Conference, February 26 - March 2, 2006, Tucson, AZ

\section{THE IIANFORD APPROACH TO COMPLIANCE}

When it became obvious that many of the Hanford and Cold War buildings would be decommissioned and demolished largely due to contamination, and that compliance with the NHPA would be an involved process, DOE-RL proposed a Programmatic Agreement to streamline the work that would be required. In 1996, the Programmatic Agreement Among the U.S. Department of Energy Richland Operations Office, The Advisory Council on Historic Preservation, and The Washington State Historic Preservation Office for the Maintenance, Deactivation, Alteration, and Demolition of the Built Environment on the Hanford Site, Washington (DOE/RL-96-77) (PA) [I] was developed and signed by DOE-RL, The Washington Office of Archaeology and Historic Preservation, and the Advisory Council on Historic Preservation.

The Programmatic Agreement identified three main commitments. First, DOE would prepare a Treatment Plan that would identify the important buildings and assign the appropriate level of documentation. Second, a comprehensive history of the plutonium production facilities would be prepared, including the individual documentation of specific buildings. Third, historic items from the buildings that had educational or interpretive value would be collected and maintained in a collection.

Over the next several years, the first commitment was met through the preparation of the Treatment Plan (Hanford Site Manhattan Project and Cold War Era Historic District Treatment Plan. Marceau 1998). The second commitment was met by the preparation of historic property inventory forms and the publication of the History of the Plutonium Production Facilities at the Hanford Site Historic District, 1943-1990 book [2].

To address the third commitment concerning Manhattan Project and Cold War artifacts in the buildings, DOE-RL began by developing a curation strategy, essentially developing criteria to guide the selection of items to be preserved, either though collection or documentation. This strategy was needed because although the buildings and artifacts at the llanford Site are historically significant, the volume of material is enormous, and many items are highly contaminated with radionuclides and chemicals. With the curation strategy developed, DOERL's team of evaluators began walking through the historic building identifying items that had scientific significance, as budgets and schedules allowed.

\section{HISTORIC PRESERVATION COMPLIANCE AT THE PLUTONIUN FINISHING PLANT}

The Hanford Cultural Resources Laboratory (HCRL) conducted a cultural resources review of the PFP decommissioning and closure project activities which would result in the entire PFP complex of buildings demolished to slab-on-grade. All buildings would be removed and disposed. Two review reports were generated: HCRC\#2002-200-048 and HCR\#2002-200-047.

The PFP complex of buildings has been evaluated as to its historic significance and 10 buildings in the complex were determined to be eligible for listing in the National Register of Historic Places as documented in HCRC\# 2002-200-021. Because the plan for the PFP complex is decontamination followed by demolition of all PFP buildings, the Hanford Cultural Resources Laboratory of the Pacific Northwest National Laboratory (PNNL) was asked to develop an 
WM'06 Conference, February 26 - March 2, 2006, Tucson, AZ

interpretive and curation plan to complete the Cultural Resources Review Interpretive Plan and Curation Plan for the Deactivation and Decommissioning of Historic Building at Plutonium Finishing Plant Complex.

The buildings at PFP that were selected by a Federal/Public working group and DOE to interpret the plutonium finishing process at the Hanford Site were 234-5Z, 291-Z, 232-Z and 2736-Z. "DOE has determined that these four buildings are eligible for inclusion in the National Register of Historic Places as contributing properties to the Hanford Site Manhattan Project and Cold War Historic District"[2]. A mitigation plan for PFP was developed, Interpretive Plan and Curation Plan for the Deactivation and Decommissioning of Historic Buildings at Plutonium Finishing Plant Complex (HCRC\# 2002-200-02) as required by the Programmatic Agreement. Mitigation through the use of historic property inventory forms and expanded historic property inventory forms was required by the PA and subsequently completed for the PFP ten historic buildings. Artifacts of historical significance were identified and tagged for preservation in Buildings 2704$\mathrm{Z}, 2736-\mathrm{ZB}, 234-5 \mathrm{Z}$ and 236-Z. The PFP table of artifacts (Table I) provides a list of the artifacts identified by the cultural and historical walk down teams.

Table 1. Artifacts of Interest at the PFP Complex of Buildings

\begin{tabular}{|c|c|c|c|c|c|c|c|c|}
\hline \multirow{2}{*}{ ltem Number } & \multirow{2}{*}{ Building } & \multirow{2}{*}{ Location } & \multirow{2}{*}{ Description } & \multirow{2}{*}{ Dimensions } & \multicolumn{3}{|c|}{ Radiologically Contamunated? } & \multirow{2}{*}{$\begin{array}{l}\text { Able to } \\
\text { Decon? }\end{array}$} \\
\hline & & & & & Yes & Unlikely & Potenilally ${ }^{67}$ & \\
\hline $234-5 Z-1798-5$ & $234-5 Z$ & $\begin{array}{l}\text { Analytical } \\
\text { Lab, Room } \\
132\end{array}$ & Mass Spectrometet & $\begin{array}{l}7 \text { fi high, } 4 \\
\text { f wide, } 2 \text { ft } \\
\text { deep }\end{array}$ & & & $\mathbf{x}$ & \\
\hline $234-5 Z-1 A$ & $234-52$ & $\begin{array}{l}\text { Analytıcal } \\
\text { Lab, Room } \\
137\end{array}$ & Spectrograph & $\begin{array}{l}9 \mathrm{ft} \text { wide, } 6 \\
\text { ft deep. } 4.5 \\
\text { ft high }\end{array}$ & & & $\mathbf{x}$ & \\
\hline $234-5 Z-2 A$ & $234-5 Z$ & $\begin{array}{l}\text { Aralytıcal } \\
\text { Lab. Room } \\
136\end{array}$ & $\begin{array}{l}\text { Emissions } \\
\text { Spectrometer }\end{array}$ & $\begin{array}{l}\text { I0 ft long. } \\
3 \text { A high, } 3 \\
\text { A dcep }\end{array}$ & $\mathbf{x}$ & & & \\
\hline $234-5 Z-3 A$ & $234-5 Z$ & $\begin{array}{l}\text { Analytical } \\
\text { Lab, Room } \\
145\end{array}$ & $\begin{array}{l}\text { Radio Flyer } \\
\text { Wagon/Fixed Array } \\
\text { Wagon }\end{array}$ & $\begin{array}{l}3 \text { ft long. } \\
1.5 \text { f wide. } \\
2 \text { f high }\end{array}$ & & & $\mathbf{x}$ & \\
\hline $234-5 Z-4 A$ & 234.52 & $\begin{array}{l}\text { Analytıcal } \\
\text { Lab, Room } \\
145\end{array}$ & $\begin{array}{l}\text { Sintering Company } \\
\text { Glove box }\end{array}$ & $\begin{array}{l}\text { It ft long. } \\
9 \text { f high, } \\
3.5 \text { f wide }\end{array}$ & $\mathbf{x}$ & & & \\
\hline $234-5 Z-9 A$ & 234.52 & $\begin{array}{l}\text { Analytical } \\
\text { Lab, Room } \\
144\end{array}$ & $\begin{array}{l}\text { Process Suppon } \\
\text { Laboratory (glove } \\
\text { boxes and hoods) }\end{array}$ & $\begin{array}{l}10 \text { f long, } \\
3 \text { ft high, } 3 \\
\text { it dcep }\end{array}$ & $\mathbf{x}$ & & & \\
\hline $234-5 Z-6 A$ & $234-52$ & $\begin{array}{l}\text { Analytical } \\
\text { Lab, Room } \\
139 \\
\end{array}$ & $\begin{array}{l}\text { Sample Prep Area } \\
\text { (glove boxes and } \\
\text { hoods) }\end{array}$ & & $\mathbf{x}$ & & & \\
\hline $234.5 Z-7 A$ & $234-5 z$ & $\begin{array}{l}\text { Analytıcal } \\
\text { Lab, Room } \\
133 \\
\end{array}$ & $\begin{array}{l}\text { Emissions } \\
\text { Spectrometer Camera }\end{array}$ & $\begin{array}{l}\text { I0 fl long, } \\
3 \text { A high. } 3 \\
\text { if decp }\end{array}$ & $\mathbf{x}$ & & & \\
\hline $234-5 Z-8 A$ & 234.52 & $\begin{array}{l}\text { Room } \\
235 D\end{array}$ & $\begin{array}{l}\text { Manntenance Dolly } \\
\text { (Universal Dolly) }\end{array}$ & $\begin{array}{l}44 \text { in. decp, } \\
82 \text { in. high, } \\
23 \text { in. wide }\end{array}$ & & & $x$ & Unknown \\
\hline \multirow[t]{2}{*}{$234-5 Z-9 A$} & $234-52$ & $\begin{array}{l}\text { Room } \\
234 A\end{array}$ & $\begin{array}{l}\text { Button Storage } \\
\text { Container }\end{array}$ & $\begin{array}{l}16 \text { in. dcep. } \\
16 \text { in. wide. } \\
25 \text { in. high }\end{array}$ & & & $\mathbf{x}$ & Probably \\
\hline & $234-5 Z$ & & $\begin{array}{l}\text { RMC Line and Control } \\
\text { Room }\end{array}$ & & $X^{(\omega)}$ & & & $\begin{array}{l}\text { No for RMC } \\
\text { line } \\
\text { components. } \\
\text { Probably for } \\
\text { RMC Control } \\
\text { Room items. }\end{array}$ \\
\hline
\end{tabular}


WM'06 Conference, February 26 - March 2, 2006, Tucson, AZ

\begin{tabular}{|c|c|c|c|c|c|c|c|c|}
\hline 234-5Z-1798-1 & 234.52 & Room 229 & $\begin{array}{l}\text { IIC-7C Feed and Prep } \\
\text { Pancl and Desk } \\
\text {. }\end{array}$ & $\begin{array}{l}86 \text { in. high, } \\
4 \text { in. deep, } \\
44 \text { in. wide } \\
\text { (pancl): } \\
15.5 \text { in. } \\
\text { decp, } 32 \text { in. } \\
\text { wide, } 35 \text { in. } \\
\text { high (desk) }\end{array}$ & & & $\mathbf{x}$ & Probably \\
\hline $234-5 Z-1798-2$ & $234.5 Z$ & Room 229 & $\begin{array}{l}\text { HC-13MD Charge Prep } \\
\text { Desk }\end{array}$ & $\begin{array}{l}30 \text { in. widc, } \\
15.5 \text { in. } \\
\text { dcep. } 35 \text { in. } \\
\text { high }\end{array}$ & & & $\mathbf{x}$ & Probably \\
\hline $234-5 Z-1798-3$ & $234-52$ & Room 229 & $\begin{array}{l}\text { IIC-17SBB Button } \\
\text { Weighing and } \\
\text { Sampling Desk (There } \\
\text { is no pancl for this } \\
\text { station) }\end{array}$ & $\begin{array}{l}24 \text { in. widc, } \\
15.5 \text { in. } \\
\text { dcep. } 35 \text { in. } \\
\text { high }\end{array}$ & & & $\mathrm{x}$ & Probably \\
\hline $234-52-4199-4$ & $234-52$ & Room 229 & Mlixung Boup $\left.\right|^{(s)}$ & & $\mathrm{NA}^{1 / 2}$ & NA & NA & Probably \\
\hline $234-5 Z-4199-5$ & $234-52$ & Room 229 & Crucible $^{(2)}$ & & NA & NA & NA & Probably \\
\hline $234-52-1798-4$ & $234-5 z$ & $\begin{array}{l}\text { Room } \\
233 / 233 \mathrm{~A}\end{array}$ & $\begin{array}{l}\text { RMA Line and Control } \\
\text { Room, including desks, } \\
\text { pancls, and } 7 \text { photo } \\
\text { albums }\end{array}$ & $\begin{array}{l}24 \text { in. long } \\
\text { by } 17 \text { in. } \\
\text { widc (desks } \\
13,14,15 \text { ); } \\
\text { desk } 9 \mathrm{C}- \\
36 \text { in. wide } \\
\text { by } 17.5 \text { in. } \\
\text { high; } 80 \text { in. } \\
\text { high by } 24 \\
\text { in. wide } \\
\text { (panel 14); } \\
\text { panc1 } 9 \AA- \\
48 \text { in. wide } \\
\text { by } 86 \text { in. } \\
\text { high }\end{array}$ & $x^{(b)}$ & & & $\begin{array}{l}\text { Very lidely no } \\
\text { contamination } \\
\text { is present in } \\
\text { RMA control } \\
\text { room. Smears } \\
\text { under some of } \\
\text { the control } \\
\text { pancls have } \\
\text { come back as } \\
\text { clean. RMiA } \\
\text { line } \\
\text { components } \\
\text { are very } \\
\text { contaminated } \\
\text { and are not } \\
\text { scheduled to } \\
\text { be decoded. }\end{array}$ \\
\hline PFP-2002-4 & $234.5 Z$ & Room 320 & $\begin{array}{l}\text { RMB Ilelium Pressure } \\
\text { Controllicr }\end{array}$ & & & & $x$ & \\
\hline PFP-2002-5 & $234-5 Z$ & Room 320 & $\begin{array}{l}\text { Glove box contaning } \\
\text { blower that serviced the } \\
\text { RMA and RMIB lines }\end{array}$ & & $\mathbf{x}$ & & & \\
\hline $2704-2 \cdot 1$ & $2704-2$ & Room 7 & Cans Typology Postcr & & & $\bar{x}$ & & \\
\hline $2704-Z-2$ & $2704-Z$ & Room II & $\begin{array}{l}\text { Demonstrationviraining } \\
\text { Cans }\end{array}$ & & & $\mathbf{x}$ & & \\
\hline $2704-2-3$ & $2704-Z$ & $\begin{array}{l}\text { Document } \\
\text { Vault }\end{array}$ & documents & & & $x$ & & \\
\hline $2736-Z-1$ & $2736-Z$ & & $\begin{array}{l}\text { Storage Vaults and } \\
\text { Conients (28 pedestals } \\
\text { used to store plitonium } \\
\text { oxides and metals) }\end{array}$ & & & & $x$ & \\
\hline $2736 \cdot 2 \mathrm{~B} \cdot 1$ & $2736-Z 13$ & Room 636 & Dry Air Glove box & & $\bar{x}$ & & & \\
\hline PFP-2002-3 & $2736-Z B$ & & $\begin{array}{l}\text { Radiation Detection } \\
\text { Device } \$ 246\end{array}$ & & & & $\mathbf{x}$ & \\
\hline PFP-2002+1 & $2736-2 C$ & $\begin{array}{l}\text { Loading } \\
\text { Dock }\end{array}$ & $\begin{array}{l}\text { 14-container metal } \\
\text { pedestals from } 2736-2 \\
\text { (Vault 4) used for } \\
\text { storage of plutorium } \\
\text { oxide and metal ( } 7.5 \text { in. } \\
\text { cans) }\end{array}$ & $\begin{array}{l}85 \text { in. high } \\
\text { by } 12 \text { in. } \\
\text { wide }\end{array}$ & & & $x$ & \\
\hline
\end{tabular}


WM'06 Conference, February 26 - March 2, 2006, Tucson, AZ

\begin{tabular}{|c|c|c|c|c|c|c|c|}
\hline PFP 20C2-2 & $2736-\mathrm{ZC}$ & $\begin{array}{l}\text { Loading } \\
\text { Dock }\end{array}$ & $\begin{array}{l}\text { Wooden mochup of } \\
\text { storage pedestals } \\
\text { (similar to pedestals } \\
\text { used in Vault I, } \\
2736-Z \text { ) }\end{array}$ & $\begin{array}{l}25.5 \mathrm{in} . \\
\text { wide by } 95 \\
\text { in. high }\end{array}$ & $x$ & & \\
\hline PRF-1 & $236-Z$ & $4^{\text {th }}$ Floor & $\begin{array}{l}\text { How Schematic for } \\
236-Z \text { Poster }\end{array}$ & & & $x$ & \\
\hline PRF-2 & $236-Z$ & $4^{b}$ floor & $\begin{array}{l}\text { Control Room Pancls } \\
\text { (No. B-3/B-A) }\end{array}$ & & & . $\mathbf{x}$ & \\
\hline
\end{tabular}

(a) Unlit.ely implies that the artifact is located in an area that is not radiologically controlked (e.g., an administrative of lice area), and consequently, no radological contamination would be expected to be found when surveyed.

(b) Potentially implies that because of where the artifact is located (i.e., in arcas controlied for radiological purposes, including areas where individuals are allowed to walk around in their streel clothes) here is the potential to encounter radiological cortamination on surfaces of the artifact when it is surveyed.

(c) Dimensions are for the glove box that houses the instrument. Height does not include legs of the glove box.

(d) The Remote Mechanical C (RMC) Line, which houses plutonium processing and stabilization equipment, is highly contaminated. The equipment in RAtC Control Room has the potential to be radiologically contaminated.

(e) This nem was not locaed during the assessmemt for preparing the mitigation/curation plan.

(f) Not applicable

(g) This $\mathrm{nem}$ was not locaed during the assessment for prepanng the mitigation/curation plan. Upon further investigation, plant personnel reported that this tem was broken inadvertently during routine surveillances and was discarded.

(h) The Remote Mechanical A (RMA) Line, which houses plutonium processing and stabilization equipment, is highly contaminated. The equipment in RMA Control Room has the potential to be radsologically contaminated.

\section{Issues regarding preservation of PFP and PFP artifacts}

The major issues that present challenges regarding the preservation of PFP buildings and artifacts are:

- The PFP process buildings are highly contaminated with residual process waste including radionuclides and chemicals

- Some of the PFP artifacts are contaminated and decontaminating them is problematic

- Some artifacts cannot be decontaminated to free release standards because of their configuration

- Sufficient proper storage for the artifacts that can be saved for curation and interpretation is not yet available

\section{Significance of Certain Artifacts}

\section{Radio Flyer}

Wagons to carry the plutonium from one area to another were used primarily to reduce exposure to workers. Reportedly, during the early years of PFP operations, operators would carry buttons, sometimes in their back pockets from area to area as needed. This practice resulted in operators receiving a significant amount of exposure from the plutonium buttons. "Radio Flyer" wagons which were readily available were modified to provide a critically safe wagon in which to transport plutonium buttons or other fissile material. Measured compartments were arranged within the wagon to keep the buttons in a critically safe configuration.

\section{"Platinum" balance}

This platinum or silver colored balance was located on the top of the RMA line. It was used to weigh the finished plutonium buttons as they were produced. The platinum color led to rumors among personnel for years that the balance was made entirely of platinum and would be very 
WM'06 Conference, February 26 - March 2, 2006, Tucson, AZ

valuable after it had been retrieved and decontaminated during the D\&D process. When the balance was investigated in 2005 , alas, it was not platinum at all.

\section{Crucible}

A ceramic crucible was used to place the plutonium material prior to firing. This formed the characteristic button of the plutonium metal disc.

\section{Mass Spectrometer}

The Mass Spectrometer is one of the largest pieces of analytical equipment at the PFP Analytical Laboratory. This is the first mass spectrometer developed for PFP. The mass spectrometer was used to determine the mass fractions or isotopes of plutonium: Pu-238, $-239,-240$. The relative fractions in individual batches were the finger print used to track plutonium for process knowledge and accountability. The use of the "mass spec" as it came to be called, allowed very fast reporting to the operations department the mass fractions of the batches being produced which allowed rapid processing of plutonium.

\section{Remote Mechanical A/Remote Mechanical C (RMA/RMC) Control Rooms}

Early plutonium workers at Los Alamos transformed plutonium nitrate paste suitable for use in weapons. Many of the steps were carried out in crude plywood enclosures. Working with plutonium directly in this fashion led to high plutonium depositions in workers. New ideas on how to protect current and future plutonium workers led to the development of remote mechanical lines to transform the plutonium nitrate paste.

The Remote Mechanical Line was used to handle and contain liquid, powder and metal plutonium along with corrosive chemical processes. Design and construction was costly and time consuming. Mounting pressure from Atomic Energy Commission (AEC) officials prompted the engineers to install glove ports to allow manual operation of the process which caused workers to call it the "Remote Mechanical by Rubber Glove Line". In 1952 the RMA line began operations and became the world's first remotely operated plutonium line.

The RMA Line contains a long row of control desks placed in front of shielding windows that are filled with water allowing the operator to view the operating equipment. Directly behind the desks are panels that contain a series of dials and recorders that allowed the operator to keep track of a carefully choreographed plutonium operation. In the 1950's, improvements in plutonium reduction and fluorination caused the RMA line to undergo a dramatic makeover (Figure 1). Most of the hoods were removed and replaced with upgraded models. The control room had to be radically shortened to accommodate these changes. 
WM'06 Conference, February 26 - March 2, 2006, Tucson, AZ

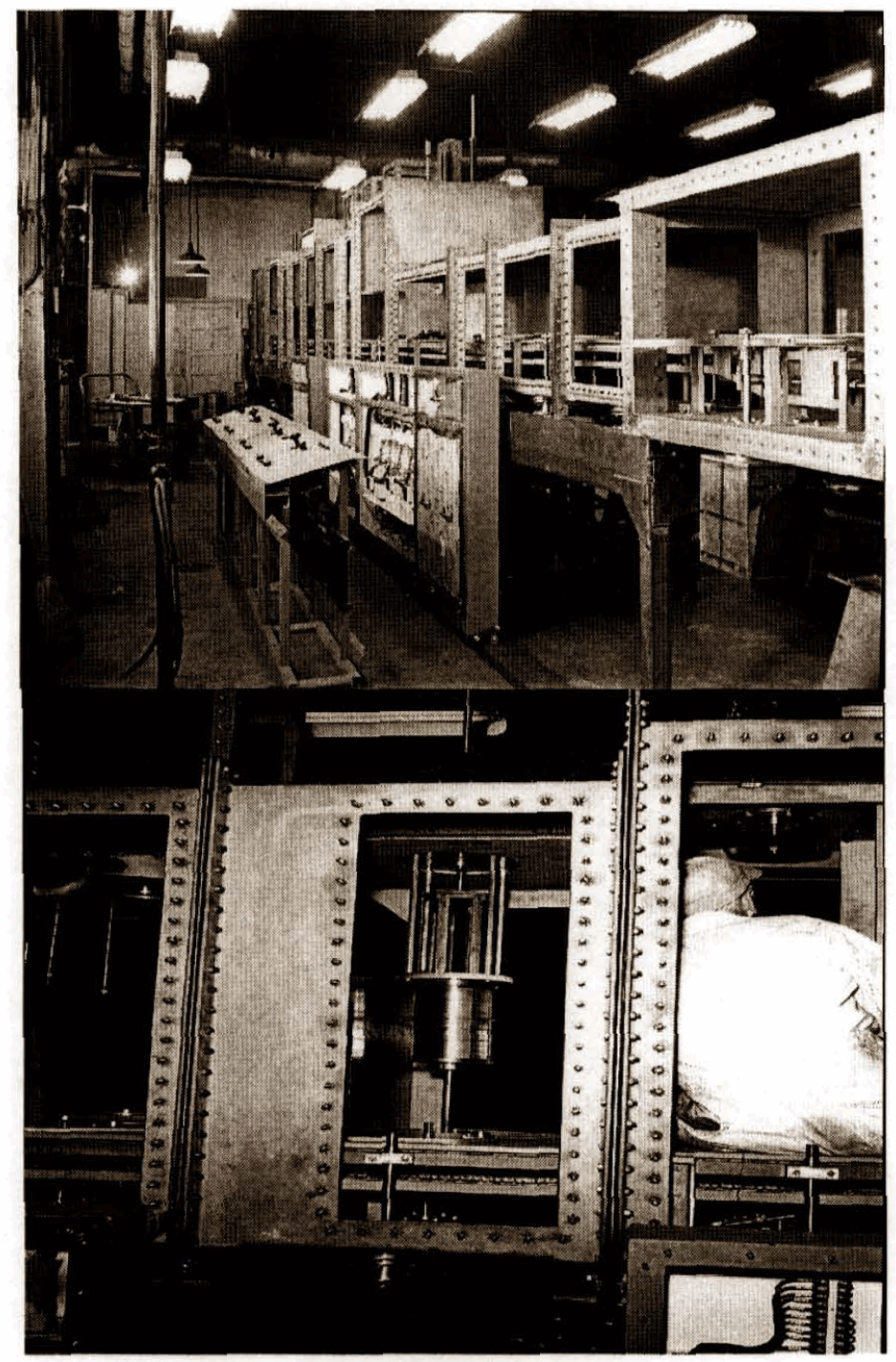

Figure 1. RMA Upgrades (1956)

The RMA Control Room last operated in 1979. Its final mission was converting fuels grade plutonium nitrate to plutonium oxide. It looks very much the same today as it did 27 years ago. Eight control panels and fifteen control desks are still in place. The room is fairly free of contamination. Personnel can access the control room without special dress or equipment and view the control room, control panels, desks and historical photographs. Also from the control room, personnel can observe the entire RMA line.

The RMC control room is much the same as the RMA control room. The RMC control room has a more modern look and is very clean from a radiological perspective. The mission of the RMC line was to convert plutonium nitrate to metal buttons for use in the fabrication section of the RMC line. Currently, access to this area is routinely made from a radiologically clean area of PFP. There is an exit door located on the north wall to allow emergency evacuations.

The RMC Control room may be recoverable for public viewing as it has very little if any contamination. Most of the unseen electronic equipment could possibly be removed to leave 
WM'06 Conference, February 26 - March 2, 2006, Tucson, AZ

behind only the buttons, knobs, gauges and faces of the equipment. This would facilitate storage of the face of the equipment and facilitate release of the equipment for public viewing. The RMA Control room will be more of a challenge due to the fact it was placed into a contamination area status for the last oxide run in 1979.

\section{History of the RMA \& RMC Production Lines}

The RMA Line was first mechanical line used for the handling of plutonium (Figure 2). Plutonium nitrate feed from the $231-\mathrm{W}$ or $231-\mathrm{Z}$ was loaded into a hood or glove box and be prepared for manufacture into weapons cores with minimal handling by operators.
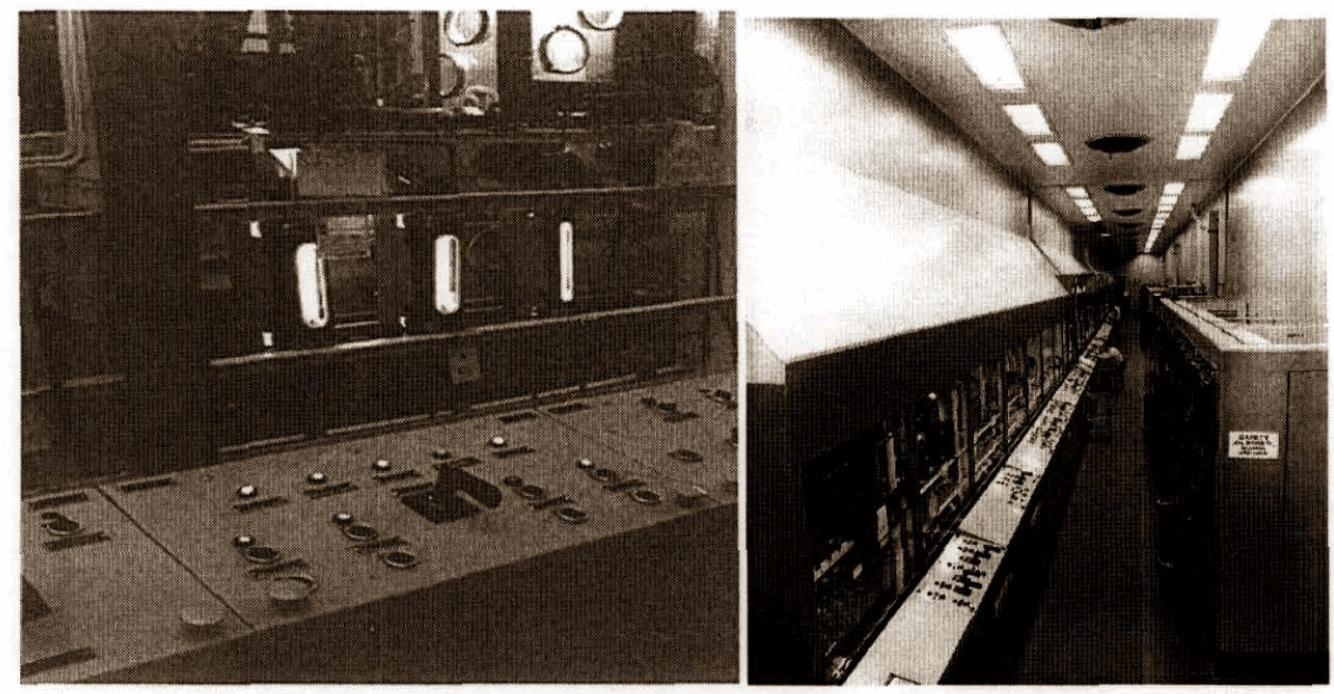

Figure 2. Photo of operating RMA line (1953)

New developments in atomic weaponry and the increased the need for production of plutonium necessitated the construction of the RMC line. The new control room would incorporate new designs from lessons learned of past RMA operations. Less space was needed to control the operations. A large portion of the electrical system was placed in the duct level above the RMC Line in an effort to reduce space for the control room. Another innovation to the new line was the ease of operator access to the glove boxes themselves. More room was available to perform maintenance activities on these glove boxes as needed.

Because of the nature of plutonium these operating areas of the RMA and RMC areas are highly contaminated. Even with highly skilled operators many accidental releases of plutonium took place in these areas. Glyptol paint (commonly known as "glyp" to the workers) was used to cover and fix (prevent contamination from being transported) contaminated surfaces. The practice of painting over contamination to "fix" the contamination is a common safety practice and will complicate the release of artifacts that have been subject to this.

Early control room operations required no protective clothing. Operators worked every day at control desks wearing street clothes. All glove box operations could be viewed through windows. Since ventilation flowed to ensure negative pressure from zone 1 (non-contaminated) to zone 3 (surface contaminated) the control rooms remained clean. 
WM'06 Conference, February 26 - March 2, 2006, Tucson, AZ

Today, workers are able to wear street clothes in the RMA Control room which contains very little fixed contamination. Several of its control panels and its accompanying control desks could possibly be unconditionally released for public viewing. By preserving this portion of the 234-5Z building, the public would be provided access to equipment that was secret or classified previously.

\section{Decontamination of Historical Artifacts}

Two of the challenges associated with the PFP artifacts concem proper storage of the artifacts and providing a venue for exhibition to the public. Additional concerns are funding for historical preservation and decontamination (as necessary) and free release of the artifacts for public viewing.

DOE requires adherence to DOE Order 5400.5 which specifies contamination levels for public release of artifacts. These public release levels represent such a low level of contamination that it is very difficult to decontaminate objects to these levels $\left(200 \mathrm{dpm}\right.$ per $100 \mathrm{~cm}^{2}$ fixed and 20 dpm per $100 \mathrm{~cm}^{2}$ removable). These levels represent "free release" levels as described in the order.

The DOE and its contractors have an obligation to public safety concerning the release of equipment formerly used in nuclear facilities. The Hanford contractors will follow the DOE order 5400.5, Radiation Protection of the Public and the Environment.

DOE Order 5400.5 states the limits for public release of material; "For alpha emitting nuclides has an average value for total surface contamination of 100 disintegrations per minute or DPM in a 100 centimeter square area." This is for fixed or hard to remove contamination. The limit for removable contamination is 20 DPM per $100 \mathrm{~cm}$ square. To meet these requirements the complete history of each artifact will be needed to accomplish a public release.

The Fluor Hanford radiological control manual states that material being released should be evaluated for internal contamination as well as contamination under any coating in accordance with DOE 5400.5. Painted surfaces on any artifact will raise questions in the minds of technicians tasked with its radiological survey. It has been the prevailing industry practice at contaminated facilities such as PFP for many years to use paint to seal contamination in place in order to protect workers. Past practice and guidance allowed radiation workers to use paint for contamination control.

Guidelines have been established to help determine a path to free releasc. Adequate release surveys of artifacts will require some kind of "background check". Listed below are questions that require an answer prior to the survey of the artifact:

- Who is responsible for the item?

- What is the item used for?

- Where has the item been?

- Has the item been decontaminated?

- Has the item been exposed to liquids?

- Has the item been exposed to airborne radionuclides? 
WM'06 Conference, February 26 - March 2, 2006, Tucson, AZ

- To which nuclide(s) has the item been exposed?

- Are there any internal surfaces that could be contaminated?

- Are the accessible surfaces porous or irregular (e.g., wood)?

- Is surface dirt, oil, paint, rust, corrosion, or grease present and could it cover contamination?

- How does the item work (potential pathways for contamination)?

3. Where is the item most likely to be contaminated and can the location(s) be surveyed?

For the RMA/RMC line control rooms for example, the question of accessible surfaces poses an obstacle for free release of certain components in each control room control panel. The top portion of the control panel is relatively flat and can be surveyed quite easily. The bottom (underneath) section presents a bigger problem (Figure 3). Wiring is not easily accessible and would be difficult to survey to meet the requirements for free release. To work around this problem most of the wiring could be cut away leaving a flat surface to survey. This would provide the top portion to display as an artifact.

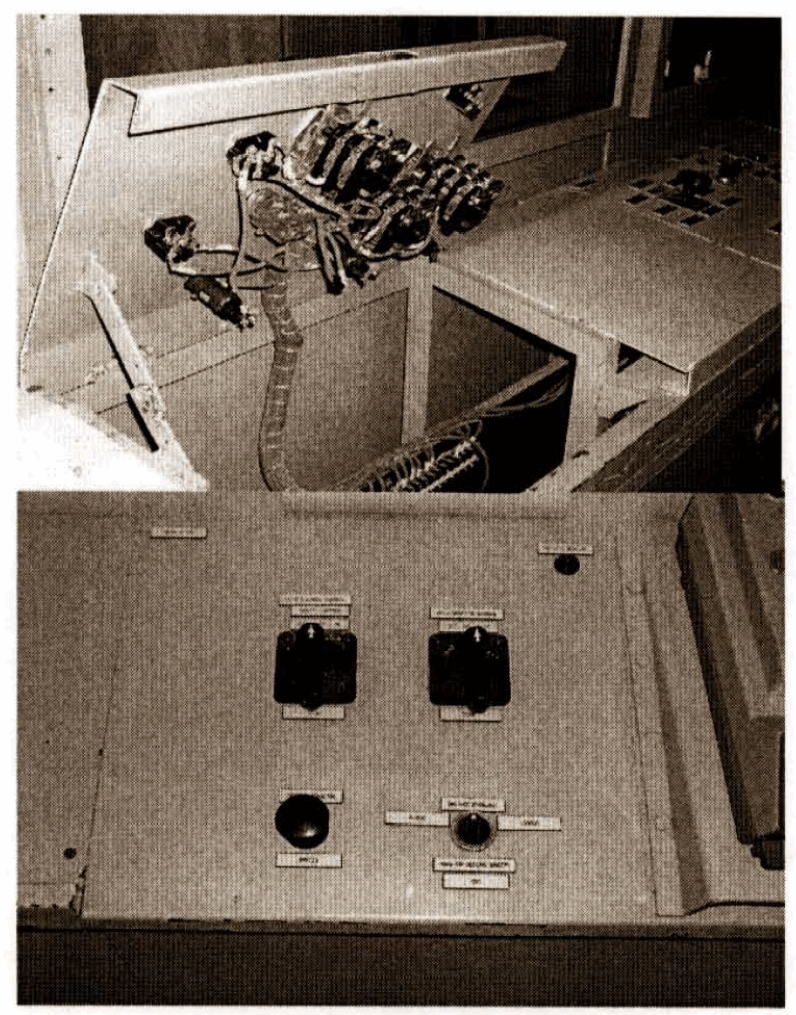

Figure 3. Underside and top of control panel.

The control room panel surfaces are flat and can be easily surveyed. The back view of the control panels illustrates the problem associated with surveying for free release of the artifact (Figure 4). 


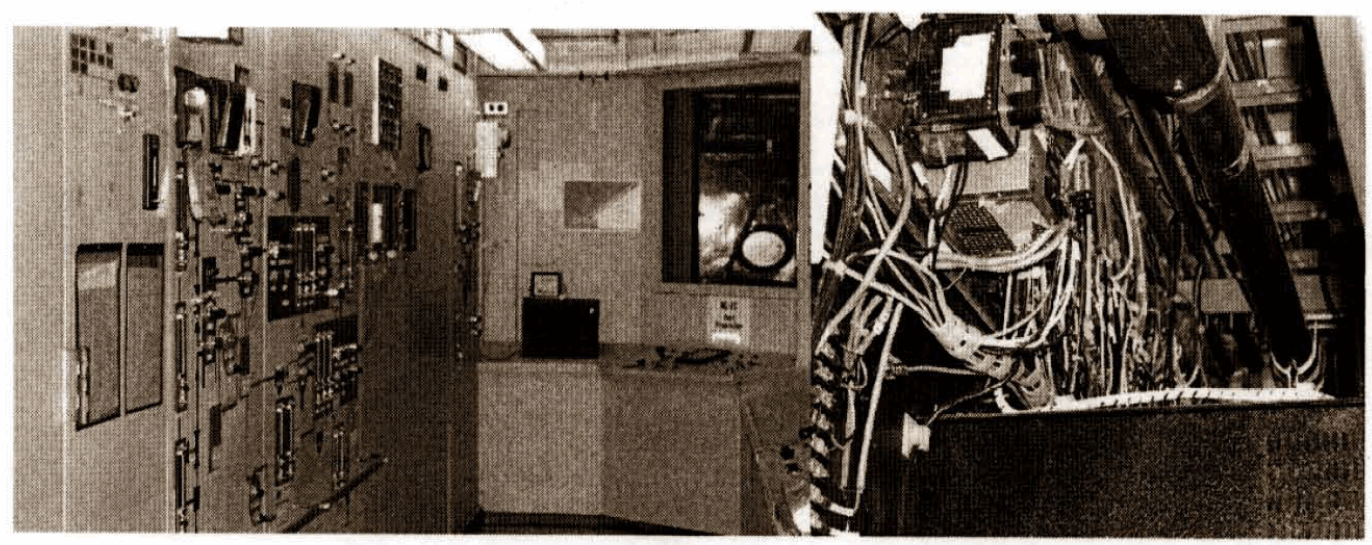

Figure 4. Front and back view of control panels.

Determining if the artifact has its original coat of paint is important to determining if the artifact can be released. Old photographs assist in determining if the artifact still has the original coat of paint or if it has been painted to fix contamination. If it looks the same today as it did originally, the comfort zone of those who will be releasing the item has increased. If these determinations can be made to the satisfaction of the Radiation Control organization, it may be possible to successfully release the artifact.

As impressive as the PFP glove boxes are, the effort to free release them would be very cost prohibitive due to the levels of contamination in the glove boxes. Therefore, photographs of each glove box and narratives regarding their background and use are important to preserve this history.

\section{Storage of Artifacts}

At this time, DOE is looking for appropriate storage for the artifacts that will be transferred from PFP as the D\&D progresses. At present there is no long-term curation facility identified that is suitable to hold the Hanford PFP collection [3].

\section{CONCLUSION}

Many of the old processing buildings at the PFP are undergoing deactivation and decommissioning and are slated for demolition. Since plutonium production had been a key mission of the Hanford Site since World War II and PFP was a major contributor throughout the Cold War, PFP has been listed for historic preservation.

DOE and Fluor Project managers at the PFP have great interest in preserving historical artifacts of the plutonium production process. At the same time, they must ensure the safety of workers and the full decontamination of buildings or artifacts.

Artifacts are being tracked and managed by PFP personnel during the D\&D process. Certain buildings and artifacts are too contaminated to preserve for public viewing and interpretation. A mitigation strategy was developed to preserve this history. The major element of the mitigation strategy was the publication Hanford Site Historic District [2]. Additionally, specific artifacts were tagged at PFP to identify them for preservation if possible. These artifacts are being 
WM'06 Conference, February 26 - March 2, 2006, Tucson, AZ

photographed and evaluated for decontamination. In some cases, the artifacts will not be released due to contamination. In other cases, artifacts will be surveyed and released for storage, curation and interpretation.

\section{REFERENCES}

1. DOE/RL96-77, Programmatic Agreement Among the U.S. Department of Energy, Richland Operations Office, the Advisory Council on Historic Preservation, and the Washington State Historic Preservation Office for the Maintenance, Deactivation, Alteration, and Demolition of the Built Environment on the Hanford Site, Washington, August, 1996.

2. DOE/RL97-1047, Hanford Site Historic District, History of the Plutonium Production Facilities, 1943-1990, April, 2002.

3. Mitigation Plan and Curation Plan for the Deactivation and Decommissioning of Historic Buildings at Plutonium Finishing Plant Complex, (HCRC\#2002-200-021) October, 2002. 